\title{
Microteaching impact on Student Teacher's Performance: A Case Study from Kuwait
}

\author{
Salwa Al Darwish ${ }^{1}$, AbdulAzeez Sadeqi ${ }^{2}$ \\ ${ }^{1}$ Public Authority for Applied Education \& Training, College of Basic Education, Kuwait \\ ${ }^{2}$ National Bank of Kuwait, Efficiency \& Governance Unit Head, Kuwait \\ Correspondence: Salwa Al Darwish, Public Authority for Applied Education \& Training, College of Basic Education, \\ AlAardiya, Block 4, Road 103. Tel: 965- 99013946. E-Mail: salwaaldarwish@ hotmail.com
}

Received: June 16, 2016 Accepted: June 30, $2016 \quad$ Online Published: July 4, 2016

doi:10.11114/jets.v4i8.1677

URL: http://dx.doi.org/10.11114/jets.v4i8.1677

\begin{abstract}
The purpose of this study is to determine the impact of micro-teaching technique in delivering the lesson to children whose first language is not English. It involved three first year English language teachers who have been teaching in elementary public schools for one year, a group of student teachers who are in their senior academic year preceding the practicum course, and the author who is senior teacher trainer. Participation in this microteaching study has provided a sense of validation for much of what these student teachers do and how they do it, which has resulted in ongoing critical reflection and peer discussion. Although initially the data shows a giving rise to anxiety among some participants, it has led to greater self-awareness and increased confidence in participants' own ability and expertise, and a endorsement of their teaching style and practice.
\end{abstract}

Keywords: Microteaching, peer- evaluation, teacher training, mediation between practice and theory

\section{Introduction}

In many countries where English is taught as a foreign language, are in need for qualified teachers to teach English as a Foreign Language (EFL). These EFL teachers to be trained are determined by the Ministry of Education, the Faculties of Education, and the teacher training colleges. In Kuwait, the quality dimension of the EFL teacher training was neglected because the courses which provide EFL teacher training and especially the application part became ineffective due to the emphasis which was mainly on theoretical and literature courses and not practice. The prospective teachers' experiences of converting the theory into practice in the actual teaching environment have great importance. Therefore, the success of an EFL teacher in the classroom as an effective instructional leader depends on being able to apply the things she/ he knows about classroom instruction in the correct format. For this reason, micro-teaching applications play an important role for the student teachers in achieving teaching skills and experiences in the natural classroom environment today.

Prior to the development of micro-teaching, specific teaching behaviors (skills) were primarily "caught" rather than taught as the teacher was immersed in full classroom teaching. The EFL student teacher out of frustration often resorted to imitating and adopting a supervising teacher's "style" of teaching without regard for his/ her own individuality or the teaching-learning situation. Moreover, every new element seems simpler after the student teacher has experienced it. Through the micro-teaching practice, EFL student teachers are provided and monitored with certain skills to enable them to follow a more objective evaluation of individual's own behaviors. As a result of the evaluation, individuals tend to make up their shortcomings, fix their errors and reinforce their positive aspects because when the need for change comes from inside an individual, she/ he is more likely to change than when the change is externally imposed.

\section{Rational}

Once the EFL student teachers start into the teaching profession, they are accompanied by extensive ordeal, discouragement, and failure. This is due to the sudden immersion into the difficulties of teaching a sophisticated concept to thirty or more students. Furthermore, based on the author's own experience, as an English language teacher trainer, she found out that teacher training courses were often not adequately preparing candidates for the teaching profession. Although courses are in unevenly packed with content, the author felt there must be a way to give EFL teaching head preparation. 
With micro- teaching practice, EFL student teachers have a qualification which prepare prospective teachers for the teaching practice which has an important role for the prospective teachers to win prior experience of teaching practice as well as the teaching profession. When the EFL student teachers begin their career with having a high self-efficacy on the classroom instruction and using the teaching methods, they are more ambitious and they work harder. The purpose of this study is to determine the impact of micro-teaching technique in delivering the lesson to children whose first language is not English, and determining the value of EFL student teachers' success by obtaining their lesson objectives through applying the micro teaching techniques as an alternative to what they have learned through the curricular components of the general teaching method. For this purpose, the author needs to find answers for the following questions:

\section{Research Questions}

(1) What pressures do student teachers go through when they practice their microteaching course?

(2) What do student teachers learn from their observation of peers in their microteaching course?

(3) How does observation in microteaching course benefit student teachers?

\section{Literature Review}

Although Allen and Ryan define micro-teaching as a teaching encounter which provides a setting for instruction in which the complexities of a normal classroom are scaled down and in which the teacher receives extensive feedback on his/her performance, they do agree that microteaching is an effective method to be applied in the pre-service and in-service stages in the professional development of teachers (1969). Others identify microteaching as a valuable instructional tool that mediates between theory and practice (Benton-Kupper, 2001). Teaching practices are the "showcase" of displaying what the teacher values, knows on subject matter in situated learning environments, and is able to do things in daily lessons (Fenstermacher \& Richardson, 2005; Hill et al., 2008). Moore et al. believe that when looking at yourself through other people's eye can be revealing and disturbing exercise at the same time (2007, p. 15). However, Moore et al. add that through observing oneself can build up strengths and provide understanding of classroom interaction (2007).

Similarly, Cuban cautions that, at times, teachers prefer simplicity over complexity (1987, p.353). Yet, if we look into the teaching practice, it follows certain intertwined steps that contributes to the quality of teaching (Ball \& Forzani, 2009; Cohen, et al., 2003; Fenstermacher \& Richardson, 2005; Lampter \& Graziani, 2009; Shulman, 2004).

Limbacher studied the differences in student teaching performance of student teachers who received micro-teaching training and those who did not (1968). He found that student teachers with micro-teaching practice performed better than student teachers who did not have micro-teaching practice prior to their student teaching experience.

Johnson reported that student teachers who completed their micro-teaching experience learned to relate to pupils, but were lacking in planning properly for content which was interpreted as a need to teach lesson planning more effectively (1973).

\subsection{Micro- teaching Impact on Student Teachers}

\subsubsection{Encouraging outlook from the Microteaching Practice}

Since microteaching cycle comprises teaching, reviewing, reflecting and re-teaching, it is important to pay close attention to every part of the process (Arends, 2000). Likewise, Sadker and Cooper believe in the importance of microteaching in creating greater awareness on teachers' behavior (1972). Among them are specific personal habits and characteristic, teaching acts and techniques, activities and interrelationships of children in the classroom, problems of structuring and pacing in the classroom, and effective acquisition of alternative teaching patterns. Fook points out that a process that is primarily focused on personal learning from personal experiences can yield concrete results and changes to other people (2006). Likewise, Beetner and Johnson conducted an assessment of the student teachers' reactions to micro-teaching practice which enable student teachers to improve their pedagogical skills in integrated teaching context through presentation and increases their range of behaviors (1968). Nevertheless, others claim that microteaching can create awareness among student teachers because they are more receptive to critiques and informs them of how to selfevaluate (Sadiq, 2011).

Lampert found out through the use of a questionnaire that student teachers' positive attitude towards microteaching is more effective compared to traditional teaching (2010). Similarly, Benton and Kupper conducted a similar study looking at student teachers' reaction to microteaching. The findings indicated interesting relationships between the number of hours of teaching preparation for microteaching and anxiety. It was found that the more student teachers taught, the less time they spent preparing for microteaching and the more student teachers practiced, the less they felt anxious. The findings also showed that as practice time increased, anxiety decreased (2001). 


\subsubsection{Adverse outlook from Microteaching Practice}

Although the above information may be true, Liderman and Gess-Newsome investigated the effect of a microteaching course on pre-service student teachers. These pre-service student teachers identified their negative beliefs, attitudes and perceptions about teaching (1989). Liderman and Gess-Newsome found as well a transition state of focus among the pre-service student teachers from concern for self to concern for students (1989).

While, Warin et al. explain that self-awareness is an essential tool for teachers and that reflective practice is critical to incorporate and make sense of the self, but also student teachers are reluctant to be involved in micro-teaching activities due to the non-natural classroom environments which reduces the efficiency of the microteaching course and creates unenthusiastic student teachers (2006).

Furthermore, Capel adds that student teachers go through a great deal of anxiety during observation when they are bridging the gap between theory and practice (1997). Therefore, when student teachers are observed it can become too thoughtful and a struggle for success on their behalf just to attract the peers and the instructor's supportive criticism (Bhargava, 2009). Moreover, Newlove found through a questionnaire which was distributed among trainees that they had a great respect for the teaching profession, but through microteaching practice it creates homogenized standard student teachers with model procedure (1969).

\section{Methodology}

\subsection{Participants \& Set- up}

This study involved three first year English language teachers who have been teaching in elementary public schools for one year, a group of student teachers who are in their senior academic year preceding the practicum course, and the author who is a senior teacher trainer. The reason for the senior teacher (author) to be as part of the study is just to triangulate the demonstration assessment feedback from the junior teachers and the peers; as well as to assure the validity of the conclusions based on the student teacher demonstration. However, the reason for choosing the three freshmen teachers just to see how they would evaluate the student teacher in their own standpoints based on their new experience in teaching. As for the group (peers), it had a total of 22 student teachers.

The student teachers followed a series of micro- teaching modules for the first two weeks of the semester presented and carried out by the author. After that, the student teachers demonstrated mini micro- teaching lessons which was fifteenminute segments for each demonstration, and ended by their presentation. As for the micro teaching modules, they consisted of instructional sessions that the student teacher should carry them out in the classroom to maximize the children's English language acquisition and for the student teacher to practice teaching in a creative way. The present study was limited to one semester.

The participants were divided into working groups of three individuals. All groups are given the same topic. They plan a short lesson sequence of the required topic, in which they include and integrate the language skills presented in the general method course and the two weeks author's explanation on how to carry on the lesson. The course included basic components:(a)classroom instruction, (b)teaching practice ,and (c) classroom management. The classroom instruction component featured two basic categories of teaching skills: interaction patterns, or methods, and (b) strategies for planning the content of lessons by meeting the lesson objectives. The teaching practice components, that is, the items that should be carried out from the warm up procedure to the wrap up step which was the student teachers' weekly practice. Through the micro-teaching, the student teachers practiced the techniques learned from the classroom component.

\subsection{Procedure}

The micro teaching class met twice a week for the duration of 3 hours per class for 14 weeks. The fourteen weeks were divided into three segments. The first segment took a duration of two weeks for the module explanation by the author and then followed by the second segment which was for seven weeks for student teachers' demonstration. However, the third segment was only five weeks. During the last two segments, each student teacher was required to teach a microclass on vocabulary items associated with any parts of the house for the third grade in the primary public schools in Kuwait. Each participant in turn presented their micro-plan to the others (Senior teacher, junior teachers, and the peers), who commented and made suggestions.

The entire demonstration was videotaped and replayed immediately so that each student teacher can see herself in action. During the seven weeks (second segment) of the course, the 22 participants gathered in a large room of the English Department in the College of Basic Education to watch the demonstration. Each student teacher from the first group of three did the demonstration. Then, the next meeting class another three were demonstrating individually, and it went on for the seven weeks. All viewers watched the demonstration of each of the 3 participants and filled out a qualitative constructed check list (Appendix (A)) and then handed to the author. After the demonstration of each of the 
three student teachers, the author presented her comments to these student teachers as a group. If her reaction to an individual's performance was particularly negative, she discussed it with her in private. During the second hour, the author led a discussion on the teaching of the first student teacher that has just been viewed, and followed by the second until all three have finished. As the author did this, she also took notes relating to the student teacher- participant's performance in two areas: her command of the language and her methodology. The other student teachers who were not performing but were viewing peers demonstration, also took notes for a future critique.

The student teacher demonstrated and presented her lesson through the following steps:

Recording with a video camera during demonstration,

Watching the demonstration which was recorded,

Evaluating the demonstration by the author, the three freshmen teachers, and the peers, also making some adjustments as a result of suggestions, contributions and criticisms of peer members and the author,

Re-preparation, re-processing and re-evaluation of the topic for the second time after getting the feedback,

Final presentation with no feedback and the EFL student teacher being graded by the author,

The research was completed over a period of 14 weeks.

Meanwhile, the author reviewed her own notes and filled out the same evaluation checklists which was used by the other student teachers in class on each student teacher, and the 3 junior teachers. It should perhaps be noted that the checklist was devised, not only as an efficient means of evaluation, but also as a way of showing the student teachers which other methods could have been used to teach the same material. Furthermore, the checklist was developed to show how serious the observers are in evaluating others . Moreover, the author listed details on any phonological or grammatical errors committed by the EFL student teacher- demonstrator. Additionally, the author indicated what approach and techniques the EFL student teacher employed. Moreover, the author evaluated the teaching of the vocabulary items by showing the EFL student teacher who was demonstrating her lesson plan which other methods could have been used to teach the same material.

These evaluation checklists which the author, the 3 freshmen teachers, and the other peer observers were filling out were given to the author on the same day of the evaluation as soon as the EFL student teacher who was demonstrating finished. The students' final grade was based on how well herself evaluation correlate with that of the author. Accordingly, the EFL student teacher was graded on the quality of her teaching, and the ability to find her strengths and shortcomings. After the second viewing (presentation), the class went through the same evaluation process with one important difference; the author didn't give a written or oral critique to the student teacher who was presenting.

\section{Data Analysis and Discussion}

This research is designed as a qualitative study which is characterized by the collection of a variety of empirical materials describing both routine and problematic moments and meanings in individuals' demonstration (Richards, 2003). A qualitative thematic analysis was employed to present measuring themes for answering the research questions. The variety of sources of information from different observers helped to maintain a healthy distance from the subject matter, in order to capture as objective an understanding of the microteaching process as possible. Two forms of feedback were received, namely, informal verbal feedback from peers, and formal written feedback from the author, the other teachers and the qualitative checklist. Furthermore, through the checklist verbal and written comments were analyzed.

\subsection{Informal Verbal Feedback from Peers}

To answer the first question: "what pressures do student teachers go through when they practice their microteaching course?", all 22 participants involved in the evaluation saw a noticeable improvement in each participant when each student teacher was teaching through the demonstration and then the presentation. Furthermore, the student teachers found in the microteaching demonstration a chance to see other peers put creative strategies into practice; as well as they benefited from the discussion around the different tactics in which they were able to use these tactics in their own practice.

\subsubsection{Peers Positive Observation Feedback}

When the whole class was observing and criticizing their fellow peer, provided them with several advantages:

- $\quad$ it expanded their experiences and reduced the fear of the actual presentations required by each student teacher once they become actual teachers;

- $\quad$ it expanded the evaluation process and informed each student teacher to weigh her own teaching performance more critically; 
- $\quad$ it resulted in a variety of creative tactics for demonstrating comparable concepts;

6.1.2 Peers Negative Observation Feedback

Additionally, through observation, these are some of the negative comments the author collected from the peers:

- $\quad$ one participant learnt that she was too repetitive in the delivery and she was blocking the screen for her peers to view the story for her lesson and most of the time she delivered incomplete sentences;

- $\quad$ Another participant after viewing her demonstration, she apprehended that she broke up informative lectures every 4 minutes with activities. This process was totally against the procedure on how to conduct the accustomed lesson plan;

- Five participants thought that microteaching class is an imitation environment. It doesn't represent the real teaching situation as well as it is subjective;

Another participant considered the microteaching practice as a traumatic technique because she had to compress the subject matter into 15 minutes, and the video- taping was frightening;

Another participant added as a non-native speaker, the videotaping through the demonstration affected her ability to choose the applicable lexes;

- Seven participants explained how it is nerve racking to present in front of their peers. This anxiety was problematic and affected their ability to share the lesson and to learn.

\subsection{Formal Written Feedback from Author and Other Teachers}

To answer the third question: "how does observation in microteaching course benefit student teachers?", the three freshman teachers' feedback described how the participants displayed a great awareness of specific personal habits and mannerism. As it shows in table (1), the student teachers demonstrated a greater awareness of specific teaching acts and techniques, particularly of the non- verbal type. For example, the warming-up step, was carried out the same by all participants once the first student teacher completed her demonstration and got an encouraging feedback from the author. Also, table (1) shows high score (3-5) for the materials being used by student teachers which impressed Junior teachers in helping the student teachers present their lessons which were accompanied by selected elements of visualization such as slides, real objects, data-shows, etc. these visual elements would assist the learners to understand.

Table (1). Junior Teachers' Average Evaluation of each Item for Each Student

\begin{tabular}{lllllllllll}
\hline & Pronun & Vocal & Fun & Body/Eye & Activities & Org. Lesson & Interesting & Teach & Instruct. & Material \\
\hline Alaa & 3.33 & 3.33 & 3.67 & 3.33 & 3.33 & 3.00 & 2.67 & 3.33 & 3.33 & 3.33 \\
Ameera & 2.33 & 3.67 & 3.33 & 3.67 & 3.50 & 3.67 & 2.67 & 3.67 & 3.00 & 3.33 \\
Anwar S. & 3.67 & 2.33 & 2.67 & 3.33 & 3.67 & 3.33 & 2.67 & 3.00 & 2.67 & 3.33 \\
Dana & 4.67 & 4.00 & 3.33 & 4.33 & 3.50 & 3.00 & 3.33 & 3.67 & 3.00 & 4.33 \\
Fajer & 4.00 & 4.00 & 4.00 & 4.67 & 4.00 & 4.33 & 4.00 & 4.00 & 4.00 & 4.67 \\
Fatema J. & 4.00 & 4.00 & 4.33 & 4.00 & 4.67 & 4.67 & 4.67 & 4.67 & 4.67 & 5.00 \\
Huda & 4.67 & 3.67 & 3.33 & 2.67 & 4.33 & 4.33 & 3.67 & 3.67 & 4.00 & 4.00 \\
Ibtihal & 2.33 & 3.00 & 3.00 & 4.00 & 3.67 & 4.33 & 4.00 & 3.67 & 4.00 & 4.00 \\
Jomana & 3.00 & 2.67 & 2.33 & 4.00 & 4.00 & 2.67 & 3.33 & 2.33 & 2.67 & 4.33 \\
Mariam A. & 4.00 & 3.67 & 4.00 & 3.67 & 4.33 & 4.33 & 3.67 & 4.00 & 4.33 & 4.00 \\
Nadia Kh. & 4.33 & 4.33 & 3.67 & 3.67 & 4.33 & 4.33 & 4.00 & 4.67 & 4.00 & 4.33 \\
Noor A & 5.00 & 5.00 & 4.00 & 4.00 & 4.00 & 4.67 & 4.33 & 4.67 & 4.33 & 4.67 \\
Noor SH. & 4.33 & 4.00 & 3.33 & 4.67 & 3.67 & 3.67 & 3.33 & 3.33 & 3.33 & 4.67 \\
Noora A. & 3.67 & 3.33 & 3.67 & 3.00 & 3.00 & 4.33 & 3.00 & 3.67 & 3.67 & 3.67 \\
Noora N. & 2.67 & 3.33 & 3.00 & 3.33 & 3.33 & 4.00 & 3.33 & 3.67 & 3.00 & 3.67 \\
Ohood A. & 4.33 & 4.00 & 3.33 & 4.33 & 3.00 & 3.67 & 3.67 & 3.67 & 3.33 & 3.67 \\
Rawan M. & 4.00 & 3.33 & 3.33 & 3.00 & 3.00 & 2.67 & 3.00 & 2.67 & 2.67 & 3.00 \\
Reem M. & 4.67 & 4.00 & 4.00 & 3.33 & 3.33 & 2.67 & 3.67 & 3.00 & 3.00 & 3.33 \\
Shaimaa K. & 4.67 & 4.00 & 2.67 & 3.33 & 3.00 & 3.00 & 2.67 & 4.00 & 3.67 & 4.33 \\
Shorouq & 3.67 & 3.33 & 3.67 & 3.00 & 3.33 & 4.00 & 4.00 & 3.33 & 3.33 & 3.33 \\
Zainab H. & 4.67 & 4.33 & 4.67 & 3.67 & 3.33 & 4.00 & 4.33 & 3.67 & 3.33 & 4.33
\end{tabular}

Results of research question two: "what do student teachers learn from their observation of peers in their microteaching course?", if we compare the average in table (1) with table (2), we would find out that there is a great inconsistencies between the peers and the junior teacher average of each item for each student. For example, the activities that were used to illustrate the topic of the lesson with junior teachers scored low (3) and high (4.67), whereas the peers score was low (2.52) and the high was (4.11). This shows that peers are more serious in their analysis and assessment than the junior teachers 
Table (2). Peers Average of each Item for each Student

\begin{tabular}{|c|c|c|c|c|c|c|c|c|c|c|}
\hline & Pronun & Vocal & Fun & Body & Activitie & Org of Lesson & Interesting & Teach & Instroc. & Material \\
\hline Alaa & 3.95 & 4.05 & 4.00 & 3.95 & 3.84 & 4.10 & 4.00 & 4.00 & 3.76 & 4.47 \\
\hline Ameera & 4.10 & 3.90 & 3.75 & 3.85 & 3.90 & 3.85 & 3.90 & 3.95 & 4.05 & 4.35 \\
\hline Anwar S. & 2.86 & 3.24 & 2.95 & 2.86 & 3.48 & 3.29 & 3.14 & 3.10 & 3.24 & 4.05 \\
\hline Dana & 4.14 & 4.05 & 3.75 & 4.10 & 3.67 & 3.71 & 3.86 & 3.90 & 3.62 & 4.14 \\
\hline Fajer & 3.81 & 3.67 & 3.53 & 3.57 & 3.74 & 3.95 & 3.90 & 3.62 & 3.76 & 4.14 \\
\hline Fatema J. & 2.00 & 2.67 & 3.45 & 3.76 & 3.57 & 2.81 & 3.05 & 2.81 & 3.43 & 3.62 \\
\hline Huda & 3.52 & 3.52 & 3.38 & 3.38 & 4.05 & 4.19 & 3.71 & 3.81 & 4.10 & 4.48 \\
\hline Ibtihal & 2.10 & 2.14 & 2.19 & 2.33 & 2.52 & 2.76 & 2.19 & 2.10 & 2.43 & 2.29 \\
\hline Jomana & 4.71 & 4.52 & 4.10 & 4.14 & 4.29 & 4.52 & 4.19 & 4.48 & 4.10 & 4.35 \\
\hline Mariam A. & 3.90 & 3.57 & 2.80 & 3.14 & 3.48 & 3.38 & 3.14 & 3.43 & 3.19 & 3.24 \\
\hline Nadia Kh. & 2.43 & 2.52 & 2.86 & 3.10 & 3.00 & 3.00 & 2.86 & 2.52 & 2.71 & 3.38 \\
\hline Noor A & 2.57 & 3.33 & 3.45 & 3.43 & 3.60 & 3.76 & 3.33 & 3.38 & 3.52 & 3.57 \\
\hline Noor SH. & 4.76 & 4.48 & 4.00 & 4.38 & 3.71 & 4.57 & 4.29 & 4.24 & 4.00 & 4.33 \\
\hline Noora A. & 3.62 & 2.48 & 2.43 & 2.67 & 2.71 & 2.76 & 2.19 & 2.71 & 2.43 & 3.29 \\
\hline Noora N. & 4.43 & 3.95 & 3.25 & 3.40 & 3.25 & 4.00 & 3.20 & 3.60 & 3.30 & 3.55 \\
\hline Ohood A. & 4.10 & 4.19 & 4.00 & 4.29 & 4.11 & 4.29 & 4.15 & 4.15 & 4.35 & 4.24 \\
\hline Rawan M. & 4.62 & 4.19 & 3.71 & 3.86 & 3.86 & 3.81 & 3.81 & 4.10 & 3.90 & 4.24 \\
\hline Reem M. & 3.33 & 3.14 & 3.33 & 2.52 & 3.48 & 3.57 & 3.33 & 3.24 & 3.52 & 4.00 \\
\hline Shaimaa K. & 2.57 & 2.57 & 2.62 & 2.62 & 3.15 & 3.33 & 2.62 & 2.67 & 3.15 & 3.45 \\
\hline Shorouq & 3.48 & 3.00 & 2.29 & 2.67 & 2.71 & 2.95 & 2.38 & 2.52 & 2.48 & 3.05 \\
\hline Zainab H. & 4.62 & 4.29 & 4.05 & 4.38 & 4.05 & 4.21 & 4.10 & 4.19 & 3.86 & 4.38 \\
\hline
\end{tabular}

Table (3) shows the evaluation for the three group observors which were involved. If we take for example pronunciation and the vocal variety, we can see the three freshmen teachers ranged between (3.57- 4.24), the peers (3.50), and the senior teacher (3.00-3.43) out of 5 which emphasized on how the student teachers delivered their lessons by using a clearer articulation, and a more standard style of speech which contains fewer reductions and constructions. Furthermore, table (3) shows high average points (3.39) for the peers evaluation in how interesting the lesson was and carried out by the demonstrators compared to teacher A (3.52), teacher B (3.81) and teacher C (3.24) and the senior teacher (2.76) sequentially. Though, for many student teachers, the demonstrations which were carried out were unclear, subsequently causing confusion as to how they were to incorporate the EFL teaching techniques that they took during their general method course into their own teaching micro-lessons. They expressed in writing that the explanations of the different teaching techniques were, at times, unclear.

Table (3). Average of the Total Evaluators for Each Item

\begin{tabular}{lllllllllll}
\hline & Pronun & Vocal & Fun & Body/Eye & Activities & Lesson & Interest & Teach & Instroc. & Material \\
\hline Junior A & 4.24 & 3.71 & 3.57 & 3.57 & 3.75 & 3.67 & 3.52 & 3.57 & 3.38 & 4.00 \\
Junior B & 3.90 & 3.67 & 3.67 & 3.76 & 3.60 & 3.86 & 3.81 & 3.76 & 3.71 & 3.90 \\
Junior C & 3.57 & 3.67 & 3.24 & 3.67 & 3.57 & 3.71 & 3.24 & 3.57 & 3.38 & 4.00 \\
Peer & 3.60 & 3.50 & 3.32 & 3.45 & 3.53 & 3.65 & 3.39 & 3.45 & 3.47 & 3.83 \\
Senior & 3.43 & 3.00 & 3.30 & 2.10 & 3.62 & 3.19 & 2.76 & 2.95 & 3.05 & 3.38 \\
\hline
\end{tabular}

Of the 22 participants who filled out the checklist, 16 wrote that the video-taped microteaching was definitely helpful. They reflected with their thoughts that the speaking subjects (demonstrators) were being evaluated in their natural setting. Many participants liked the idea so much that they requested that during their practicum they should be videotaped. Ten out of the 22 participants had difficulties preparing and presenting their lesson according to the author's guidelines. One student teacher's comment" we have struggled in organizing our lesson plan according to the Instructor's (author) guidelines.

Table (4). Standard Deviation for each Item by each Evaluator

\begin{tabular}{|c|c|c|c|c|c|c|c|c|c|c|}
\hline & Pronun & Vocal & Fun & Body/Eye & Activities & Lesson & Interest & Teach & Instroc. & Material \\
\hline Junior A & 0.995 & 0.902 & 0.926 & 0.926 & 0.967 & 1.017 & 0.981 & 1.326 & 1.322 & 1.049 \\
\hline Junior B & 1.179 & 1.065 & 1.197 & 0.831 & 0.995 & 1.108 & 0.928 & 1.091 & 1.146 & 1.179 \\
\hline Junior C & 1.434 & 1.111 & 1.221 & 1.238 & 0.926 & 1.146 & 1.221 & 1.028 & 0.921 & 1.000 \\
\hline Peer & 1.285 & 1.248 & 1.189 & 1.157 & 1.097 & 1.139 & 1.174 & 1.164 & 1.132 & 1.210 \\
\hline Senior & 1.076 & 1.183 & 1.455 & 1.179 & 1.284 & 1.504 & 1.446 & 1.564 & 1.802 & 1.322 \\
\hline
\end{tabular}

Overall, in table (4) the peer standard deviation for all the items were close and significant which shows how much the amount of instruction devoted to the scope and sequence of the syllabus component was a contributor to their understandings of the different teacher-centered and learner-centered teaching strategies. For example, they reported that the demonstration procedures carried out by different student teacher for the different teaching techniques served as diagram to aid their conceptualization of what and how to teach. Also, for them, the amount of academic learning time, 
namely, time on task, was seen as having an impact on their understandings of the different teaching strategies.

However, a troublesome area for them was the way in which their instructors for previous courses such as the general method course, incorporated different methods for teaching EFL in their classrooms. Student teachers stated that timeworn methods for EFL teaching techniques as teaching examples was used instead of the instructors presenting modernized EFL teaching techniques to be learned.

\subsubsection{Positive Impact from the Demonstration}

To answer question two and three, the student teachers remarked that certain types of feedback which occurred during the demonstration had an impact on increasing student teacher's comprehension of specific goals. They viewed the idea of receiving feedback during the demonstration sessions as being an important aspect of instruction. For example, the evaluation of their micro-teaching demonstration performance had positive feedback over an extended period of time from their peers' demonstration about their level of understandings of the different teaching strategies on how to implement a lesson plan from A to $\mathrm{Z}$.

The student teachers stated that when they were receiving their feedback on various steps of their teaching skills, was a representative of the types of feedback which contributed to their understandings of the teaching techniques. For example, the construction and phrasing of different types of questions at various cognitive levels was helpful to pace the flow of instruction. In addition, student teachers found that the researcher's classroom instruction (modules) contributed to their understandings. For example, they reported that the demonstrations from their peers for the different teaching techniques and the using of materials served as representation to aid their conceptualization of what and how to teach. In part, student teachers were able to apply what they learned about the teaching tactics, coupled with associated teaching skills, to logically develop a plan for presenting EFL to primary students.

Overall, student teachers stated that the amount of instruction devoted to the scope and sequence of the curricular component (micro- teaching modules) was a contributor to their understandings of the different teacher-centered and learner-centered teaching strategies. For them, the amount of time on task had an influence on their understandings of the different teaching strategies.

\subsubsection{Negative Impact from the Demonstration}

A troublesome area was for student teachers in which they stated that the steps where the student teachers were demonstrating these models of teaching techniques as teaching examples should have been explained before the peers' demonstrations. For many of the student teachers, the demonstrations were unclear, subsequently causing confusion as to how they were to incorporate the teaching tactics into their own teaching micro-lessons. They expressed that the explanations of the different teaching techniques were, at times, unclear.

The three freshmen teachers remarked that certain types of feedback which occurred had an impact on increasing student teacher's comprehension of specific goals. They viewed the idea of receiving feedback during the classroom sessions as being an important aspect of instruction. For example, while student teachers have received positive feedback on their checklist evaluation from their peers for their teaching performance, they did not receive a similar type of feedback from their instructors (author) with regard to their evaluation of their micro-teaching demonstration. In addition, the student teachers interest for the peers' usage of different tactics were not used in a supportive way thus distracting them from acquiring improved understandings of the different teacher-centered and learner-centered teaching strategies. Furthermore, they emphasized, above all, that the feedback they got from the author in the classroom, regardless of its form, must be expressed with care and concern for the involved individual.

\section{Conclusion}

In microteaching course, the student teachers acquainted themselves with the success of their performance which enabled them to evaluate and to improve their teaching behavior. Through the microteaching sessions, the student teachers engaged in dialogues with their peers as well as their lecturer, and found a way to create new scripts for their work in the classrooms (Beattie, 2007). Besides, the impact of the microteaching course was positive for the individual teaching practice and helped the student teachers in how to approach the course practically and deliver the information through collaboration with peers. As Brown mentioned, through observing a fellow student teacher and using a trial and error in own teaching sessions are very common way of self- training (1975). The author's findings from this study show that many student teachers have learnt from peers and from reflection from their own teaching when they were watching the video- tape. A lot of training skills the student teachers gained through their observation which:

1. increased the chance of the transfer of an innovation from the training session into classroom practice;

2. tested participants' understanding of the new teaching skill.

In addition, the microteaching sessions lead the student teachers to be more conscious of their classroom behavior. 
Likewise, the author wanted some assurance that they were capable of meaningful self- evaluation, as well as the feeling of growth as a teacher might continue.

Additionally, keeping records of teaching through the micro- teaching sessions has a great value as they provide an excellent means of studying a participant's command of grammar and phonology. Likewise, the participant were being evaluated in their natural environment, and were graded based on their common use of EFL, not an artifact that the Ministry of Education had created for testing purposes.

Through the microteaching sessions, the student teachers organized practice teaching. They were very communicative with the planning process, and felt that it was adaptable for normal classroom teaching and focused on specific skills. Since the goal is to give instructors confidence, support, and feedback by letting them try out among friends and colleagues a short slice of what they plan to do with their students, with microteaching session it encouraged the students in synthesizing information about the topic, encouraged a great relationship of motivation and discovered more information between previous and present structured teaching technique.

However, student teachers also expressed that during the presentation, they felt anxious due to the feeling of being observed. The main limitation of microteaching is time limitation but the method is effective for proper understanding.

\section{References}

Allen, D., \& Ryan, K. (1969). Micro-teaching. Reading: MA: Addison Wesley.

Arends, R. I. (2000). Learning to Teach. New York: McGraw-Hill.

Ball, D. L., \& Forzani, F. M. (2009). The work of teaching and the challenge for teacher education. Journal of Teacher Education, 60, 497-511. http://dx.doi.org/10.1177/0022487109348479.

Beattie, M. (2007). The art of learning to teaching: creating professional narratives. $\left(2^{\text {nd }}\right.$. Ed.) New Jersey: Pearson Prentice Hall.

Beetner, E., \& Johnson, W. D. (1968). A survey of student teacher reactions to micro-teaching practice. Unpublished manuscript, University of Illinois, Teaching Techniques Laboratory, Urbana-Champaign, IL.

Benton-Kupper, J. (2001). The microteaching experience: Student perspectives. Education, 121(4), 830-835

Bhargava, A. (2009). Teaching practice for student teachers of B. Ed program: Issues, predicaments \& suggestions. Turkish Online. Journal of Distance Education, 10(2), 101-108.

Brown, G. (1975). Microteaching: A programme of Teaching Skills. London: Methuen and Co. Ltd.

Capel, S. A. (1997). Changes in student's anxieties and concerns after their first and second teaching practices, Educational Research, 39, 21-28. http://dx.doi.org/10.1080/0013188970390208

Cohen, D. K., Raudenbush, S. W., \& Ball, D. L. (2003). Resources, instruction, and research. Educational Evaluation and Policy Analysis, 25, 119-142. http://dx.doi.org/10.3102/01623737025002119

Cuban, L. (1987).The Holmes Group Report: Why Reach Exceeds Grasp. Teachers College Record, 88(3), 348-351. http://dx.doi.org/10.1177/002248718703800405

Fenstermacher, G. D., \& Richardson, V. (2005). On making determinants of quality in teaching. Teachers College Record, 107, 186-213. http://dx.doi.org/10.1177/00224669060400020201

Fook, J. (2006). Beyond Reflective Practice: reworking the "critical" in critical reflection. Keynote presented at lifelong learning Conference, Leeds Institute of Medical Education.

http://www.leeds.ac.uk/medicine/meu/lifelong06/papers/P_JanisFook.pdf.

Hill, H. C., Blunk, M. L., Charalambous, C. Y., Lewis, J. M., Phelps, G. C., Sleep, L., \& Ball, D. L. (2008). Mathematical knowledge for teaching and the mathematical quality of instruction: An exploratory study. Cognition and Instruction, 26, 430-511. http://dx.doi.org/10.1080/07370000802177235

Johnson, W. (1973). An analysis of the teacher performance appraisal scale. Unpublished manuscript, University of Illinois, Teaching Techniques Laboratory, Urbana-Champaign, IL.

Lampert, M. (2010). Learning teaching in, from, and fro practice: What do we mean? Journal of Teacher Education, 60, 21-34. http://dx.doi.org/10.1177/0022487109347321

Lampert, M., \& Graziani, F. (2009). Instructional activities as a tool for teachers and teacher educators' learning. The Elementary School Journal, 109, 491-509. http://dx.doi.org/10.1086/596998. http://dx.doi.org/10.1086/596998

Lederman, N. G., \& Gess-Newsome, J. (1989). A qualitative analysis of the effect of a microteaching course on pre-service science teachers instructional decisions and beliefs about teaching. Retrieved from ERIC database 
(ED305254)

Limbacher, P. C. (1968). A study of the effects of microteaching experiences upon practice teaching classroom behavior. (Doctoral dissertation, University of Illinois, 1968).Dissertation Abstracts International, 30, 189A.

Moore, S., Walsh, G., \& Risquez, A. (2007). Teaching at college and university effective strategies and key principles. Maidenhead: Open University Press.

Newlove, B. W. (1969). The 15-Minute Hour: An early teaching experience Report Series No. 23. Retrieved from ERIC database (ED040154).

Richards, K. (2003). Qualitative inquiry in TESOL. Palgrave MacMillan.

Sadiq, A. W. A. I. (2011). Student teachers' microteaching experiences in a pre-service English teacher education program. Journal of Language Teaching and Research, 2(5), 1043-1051. http://dx.doi.org/10.4304/j1tr.2.5.1043-1051

Sadker, M., \& Cooper, J. M. C. (1972). What do we know about microteaching? Educational Leadership, 29(6), 547-551.

Shulman, L. S. (2004). The wisdom of practice: Essays on teaching, learning, and learning to teach. San Francisco, CA: Jossey-Bass.

Warin, J., Maddock, M., Pell, A., \& Hargreaves, L. (2006). Resolving identity dissonance through reflective and reflexive practice in teaching. Reflective Practice, 7(2), 233-245. http://dx.doi.org/10.1080/14623940600688670

Index (A)

Demonstration \&Presentation Assessment

Statements were marked according to the following scale: 5 High, 1 Low

\begin{tabular}{llllll}
\hline Student Teacher's Name & 5 & 4 & 3 & 2 & 1 \\
\hline Pronunciation & & & & & \\
Vocal Variety & & & & & \\
Fun Factor & & & & & \\
Body Language/ Eye Contact & & & & & \\
Choice of Activities & & & & \\
Organization of Lesson & & & & \\
Interesting & & & & \\
Teachability & & & & \\
Adaptation of Instruction & & & \\
Material Used & & & & \\
\hline
\end{tabular}

This work is licensed under a Creative Commons Attribution 3.0 License. 